\title{
Effect of Roasting Temperature on the Fatty Acid Composition and Physicochemical Characteristics of Extracted Oil Carthamus tinctorius Thori-78 of Pakistani Origin Seeds
}

\author{
Razia Sultana*, Rubina Saleem and Ambrat \\ Applied Chemistry Research Center, PCSIR Laboratories Complex, \\ Shahrah-e-Dr.Salimuzzaman Siddiqui, Karachi-75280, Pakistan
}

(received June 25, 2010; revised October 7, 2010; accepted October 22, 2010)

\begin{abstract}
Study of Carthamus tinctorius L. (safflower) oil extracted from unroasted and roasted seeds (at temp 120-180 ${ }^{\circ} \mathrm{C}$ ) showed, on roasting, significant increase in free fatty acid, acid value, unsaponifiable matter, rancidity, peroxide value, colour development and oxidative deterioration, while refractive index and density were relatively constant. The iodine value of oil of seeds roasted at 160 and $180{ }^{\circ} \mathrm{C}$ was reduced. The concentration of oxidation-sensitive linoleic acid reduced from 75.42 to $73.41 \%$ but that of palmitic and stearic acids increased, showing no adverse effect on the nutritional value of the roasted seed-oil. But at higher temperature $\left(180^{\circ} \mathrm{C}\right)$ the browning of seeds occurred.
\end{abstract}

Keywords: C. tinctorius Thori-78, roasted-seed oil, fatty acids, vegetable oil

\section{Introduction}

Carthamus tinctorius L. (safflower) is an annual herb belonging to the family Compositae. It is widely distributed through out the world such as Asia, USA, Canada, Africa and Australia. India, Africa and USA are the main producers of safflower oil. It has long been extensively grown for obtaining a dye from the flowers as well. This oil crop was introduced into Japan from China, where it became an important source of cooking oil (Oyen and Umali, 2007; Knights et al., 2001; Kaffka et al., 2000; Sastri, 1950). From Middle East, the crop also spread to Europe and then to America and Africa. C. tinctorius flowers, seeds and oil have a wide range of medicinal uses in different countries (Kaffka et al., 2000; Sastri, 1950). In northern America, the plant is cultivated for using as bird seed, animal meal and industrial applications (Oyen and Umali, 2007; Mündel et al., 2004; Oelke et al., 1992).

C. tinctorius seeds are edible and are also eaten after roasting like sunflower seeds (Duke, 1983). The seed is rich in edible oil and oil content is similar to olive, sunflower and peanut oils. The oil content varies from 24 to $36 \%$, depending on the variety of $C$. tinctorius, soil texture, climate and other conditions (Pritchard, 1991; Swern, 1964). The oil is composed of linoleic acid (67.7-83.2\%), the essential fatty acid that the human body is unable to biosynthesize (Hamrouni

*Author for correspondence; E-mail: razias@hotmail.com et al., 2004, Lee et al., 2004). Hence the seeds and seed oil are therapeutically important.

C. tinctorius oil can be used in cosmetics, foods, nutritional supplements, personal care products, soap and shampoos. Developed countries have the most significant market for C. tinctorius oil as salad oil, margarine and cooking oil, as it is non-allergenic and is considered to be one of the healthiest oils for human consumption with a high ratio of polyunsaturated/ saturated fatty acids.

Roasting process is the primary step for making condiment oil since the colour, flavour, composition and quality of oil are all influenced by the processing conditions. C. tinctorius oil is used as condiment oil along with sesame, red pepper and perillar oils in Korea (Lee et al., 2004; Kim et al., 2002a; 1998; Yoshida and Takagi, 1997). Recently, use of roasted C. tinctorius safflower seed was investigated as medicinal food for bone formation in Korea and the powder of roasted $C$. tinctorius seeds was found to help in recovery of bone repair in rats (Kim et al., 2002b; 1998).

In Asia roasted seeds of $C$. tinctorius are commonly consumed. Hence, the objective of the present study was to investigate the changes in physical and chemical indices of unroasted and roasted seed oil of C. tinctorius Thori-78 and correlate the results of physicochemical parameters of oil to evaluate the 
quality of seed for edible purpose. At high temperatures, free fatty acids, peroxide value and oxidative deterioration of oil was found to be high; it was further confirmed by fatty acid profile that linoleic acid content decreased while that of palmitic, stearic and oleic acids slightly increased whereas iodine value was reduced upon roasting. This is evident from the results at high temperature $\left(180^{\circ} \mathrm{C}\right)$.

\section{Materials and Methods}

Plant material. Carthamus tinctorius Thori-78 seeds were purchased from Oilseeds Botanist Agriculture Research Institute Tandojam, Sindh, Pakistan. The fruit is an achene (dry, one seeded with a thin hull). It resembles sunflower seed but is smaller in size and of creamy color. It is irregularly pear-shaped, smooth, shiny and up to $10 \mathrm{~mm}$ long.

Reagents. Solvents and chemicals such as $n$-hexane (95\%), $n$-heptane (99\%), ethanol (95\%), carbon tetrachloride (95.5\%), chloroform (99.5\%), methanol (98.8\%), sulphuric acid (95.98\%), hydrochloric acid (37\%), acetic acid (100\%), glacial acetic acid (99.5\%); sodium hydroxide (98\%), potassium hydroxide (98\%), sodium thiosulphate penta hydrate (R.G.), oxalic acid (extra pure), potassium dichromate (extra pure), potassium iodide (extra pure), iodine mono-chloride (R.G.) and anhydrous sodium sulphate were purchased from E. Merck (Darmstadt, Germany) and Labscan (Bankok, Thailand). Standards of fatty acid methyl esters were purchased from Supelco (Bellefonte, PA, USA) and Sigma Aldrich Co. (St. Louis, MO, USA).

Apparatus. The instruments used included gas chromatograph with flame ionization detector, Model Clarus 500, purchased from Perkin Elmer Instruments LLC (Shelton, CT, USA), capillary column Rtx-2330 $(60 \times 0.25 \mathrm{~mm} \times 0.20 \mu \mathrm{m}$, film thickness) from Supelco (Bellefonte, PA, USA), UV spectrophotometer Nicollet Evolution 300 (Cambridge, UK), Lovibond model E tintometer (Salisbury, UK), Abbé Refractometer Model 2W (Shijiaahuang, China), Electric oven Model LR-271C with thermostat sets (Florida, USA) and Vacuum oven (Melrose Park, IL, USA).

Roasting of seeds and oil extraction. C. tinctorius Thori-78 seeds were roasted at 120, 140, $160 \& 180$ ${ }^{\circ} \mathrm{C}$ for 20 mins each using electric oven. Unroasted and roasted seeds (200 g of each batch) were separately crushed and finely ground to flour and then subjected to extraction with $n$-hexane in a Soxhlet extractor for
$8 \mathrm{~h}$ (AOCS, 2004). Fat was recovered using a rotary evaporator and the extracted fat was dried over anhydrous sodium sulphate, transferred to a capped bottle and stored at $4{ }^{\circ} \mathrm{C}$ until used for analysis.

Colour determination. Oil samples extracted from roasted and unroasted seeds were placed in a 1 inch cell, and the colour was determined using a Lovibond tintometer model E (Salisbury, England) at room temperature $\left(35^{\circ} \mathrm{C}\right)$ through making the best possible match with the standard colour slides of red and yellow indices.

Determination of colour development. Colour development was measured through absorbance at $420 \mathrm{~nm}$ of $5.0 \%$ (W/V) solutions of oils in chloroform, using UV Spectrophotometer (Nicolet Evolution 300, Cambridge, UK).

Determination of oxidative deterioration of oil. Deterioration of the roasted and unroasted extracted oil was determined following the analytical method 2.505 described in IUPAC (1987). Oil samples were dissolved in isooctane. A Nicolet Evolution $300 \mathrm{UV}$ Spectrophotometer, with the software "VISIONpro", was used to determine absorbtivity at $\lambda_{\text {(max) }} 232$ and $270 \mathrm{~nm}$.

Fatty acid composition. Methyl esters of fatty acids were prepared according to standard IUPAC method 2.301 (IUPAC, 1987). Chemical composition of fatty acid methyl esters was accomplished with a Perkin Elmer gas chromatograph model Clarus 500 fitted with a polar capillary column Rtx-2330 $(60 \times 0.25 \mathrm{~mm}$ $\times 0.20 \mu \mathrm{m}$, film thickness) and a flame ionization detector. Nitrogen was used as carrier gas at flow rate of $3 \mathrm{~mL} / \mathrm{min}$. Other conditions were as follows: initial oven temperature, $70^{\circ} \mathrm{C}$ for 5 mins ramped at $10^{\circ} \mathrm{C} /$ min to $180{ }^{\circ} \mathrm{C}$ and then ramped at $3{ }^{\circ} \mathrm{C} / \mathrm{min}$ to final temperature $220^{\circ} \mathrm{C}$ where it was held for 8 mins; injector temperature, $270{ }^{\circ} \mathrm{C}$; detector temperature, $270{ }^{\circ} \mathrm{C}$. A sample volume $0.3 \mu \mathrm{L}$ was injected; (split less). Fatty acid methyl esters were identified by comparing their relative and absolute retention times of standards of fatty acid methyl esters. The quantification was done by a built-in data-handling programme, provided by the manufacturer of the gas chromatograph. The analyses were performed in triplicate.

Physical and chemical analysis of the extracted oil. The oils extracted from unroasted and roasted oil samples were analyzed by adopting the methods of 
American Oil Chemist Society (AOCS, 2004). For determination of refractive index, density, free fatty acid, acid value, peroxide value, rancidity, iodine value, unsaponifiable matter, colour, colour development and deterioration of oil, UV-spectrophotometer was used. The colour of oil was determined by Lovibond Tintometer (Tintometer Ltd., Salisbury, UK) using 1" cell.

\section{Results and Discussion}

Seeds were roasted at $120,140,160$ and $180{ }^{\circ} \mathrm{C}$ for 20 mins. The hexane-extracted oil contents of unroasted and roasted samples of $C$. tinctorius Thori-78 are shown in Table 1. Physical and chemical characterization of unroasted and roasted seed-oil samples are depicted in Tables 1 and 2. It was noticed that as the roasting temperature increased, slight increase in oil content from 28.33 to $29.64 \%$ occurred which may be due to rapid evaporation of moisture at high temperature.

The values of FFA (\%) as OA (oleic acid) and acid value also increased with the increase in roasting temperature (Fig. 1). Seed samples showed a significant increase in peroxide value and rancidity at high roasting temperature $\left(160\right.$ and $\left.180^{\circ} \mathrm{C}\right)$, as depicted in Fig. 2, as a result of formation of more hydroperoxides at these temperatures. The absorptivity at 232 and $270 \mathrm{~nm}$, due to the formation of conjugated dienes and trienes, was a good index for measuring the oxidative degradation of oil. The extent of oxidative deterioration of the oil samples were measured by UV spectrophotometer. The values of absorptivity at $232 \mathrm{~nm}$ and
$270 \mathrm{~nm}$ increased from the room temperature to $180^{\circ} \mathrm{C}$ (Fig. 3). As the roasting temperature increased, the oxidative deterioration of oil also increased resulting in formation of primary and secondary products in the seeds (Khatoon and Krishna, 1998; Vieira et al., 1998; Albi et al., 1997; Yen and Shyn, 1989).

The colour of unroasted and roasted oil samples was measured on Lovibond Tintometer; the result showed increase in red and yellow units with the increase in temperature (Fig. 4). Intense color of the vegetable oil depends mainly upon the presence of various colouring pigments of plants such as carotenoids, chlorophyll etc. which are effectively removed during refining and bleaching steps of oil processing. The vegetable oils with minimum values of colour index are good for edible purpose.

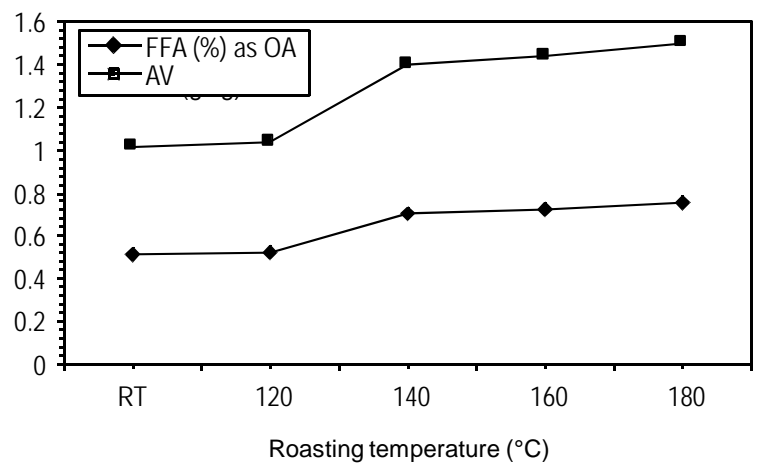

Fig. 1. FFA and $A V$ values at different roasting temperature $\left(\mathrm{RT}=35^{\circ} \mathrm{C}\right)$.

Table 1. Characteristics of unroasted and roasted seed-oil of C. tinctorius Thori-78

\begin{tabular}{|c|c|c|c|c|c|}
\hline \multirow[t]{2}{*}{ Parameters } & \multirow{2}{*}{$\begin{array}{l}\text { Unroasted seed oil } \\
\text { (at room temperature) }\end{array}$} & \multicolumn{4}{|c|}{ Roasted-seed oil at different temperatures } \\
\hline & & $120^{\circ} \mathrm{C}$ & $140^{\circ} \mathrm{C}$ & $160^{\circ} \mathrm{C}$ & $180^{\circ} \mathrm{C}$ \\
\hline Oil content (\%) & 28.33 & 28.63 & 28.74 & 29.12 & 29.64 \\
\hline Free fatty acid (\% as OA) & 0.51 & 0.52 & 0.70 & 0.72 & 0.75 \\
\hline Acid value (g/kg) & 1.12 & 1.04 & 1.40 & 1.44 & 1.50 \\
\hline Peroxide value (meq/kg) & 17.2 & 19.35 & 19.40 & 40.14 & 42.42 \\
\hline Rancidity & Incipient & Rancid & Rancid & Highly rancid & Highly rancid \\
\hline Iodine value ( $\mathrm{g}$ of $\mathrm{I}_{2} / 100 \mathrm{~g}$ oil) & 134.82 & 135.10 & 134.90 & 133.57 & 132.99 \\
\hline Unsaponifiable matter (\%) & 0.4132 & 0.5601 & 0.7025 & 0.7210 & 0.8980 \\
\hline Refractive index at $40{ }^{\circ} \mathrm{C}$ & 1.4734 & 1.4732 & 1.4730 & 1.4730 & 1.4730 \\
\hline Density at $24{ }^{\circ} \mathrm{C}$ & 0.9100 & 0.9101 & 0.9121 & 0.9151 & 0.9154 \\
\hline Density at $40{ }^{\circ} \mathrm{C}$ & 0.9064 & 0.9087 & 0.9088 & 0.9097 & 0.9100 \\
\hline Colour 1" cell (red unit) & 1.4 & 1.5 & 1.6 & 2 & 4.3 \\
\hline (yellow unit) & 25 & 26 & 26 & 35 & 70 \\
\hline (neutral unit) & 0.71 & 0.1 & 0.8 & 0 & 0 \\
\hline \multicolumn{6}{|l|}{ Colour determination } \\
\hline$\lambda_{(\max )} 420 \mathrm{~nm}(\mathrm{w} / \mathrm{v} 5 \%)$ & 0.018 & 0.031 & 0.068 & 0.073 & 0.118 \\
\hline Absorbtivity at $\lambda_{\text {(max) }} 232 \mathrm{~nm}$ & 4.585 & 4.611 & 4.714 & 4.726 & 4.779 \\
\hline at $\lambda_{(\max )} 270 \mathrm{~nm}$ & 3.399 & 3.481 & 3.571 & 3.611 & 3.700 \\
\hline
\end{tabular}


Table 2. Fatty acid composition (wt \%) of unroasted and roasted high linoleic seeds oil of $C$. tinctorius Thori-78

\begin{tabular}{llllll}
\hline \hline Fatty acids & $\begin{array}{l}\text { Unroasted } \\
\text { seed oil } \\
\text { (room } \\
\text { temperature) }\end{array}$ & \multicolumn{4}{c}{$\begin{array}{l}\text { Oil from seeds roasted } \\
\text { at different temperatures }\end{array}$} \\
\cline { 5 - 7 } & $120{ }^{\circ} \mathrm{C}$ & $140{ }^{\circ} \mathrm{C}$ & $160{ }^{\circ} \mathrm{C}$ & $180{ }^{\circ} \mathrm{C}$ \\
\hline $\begin{array}{c}\text { Palmitic acid } \\
\left(\mathrm{C}_{16: 0}\right)\end{array}$ & 6.45 & 7.35 & 7.17 & 7.03 & 7.04 \\
$\begin{array}{c}\text { Stearic acid } \\
\left(\mathrm{C}_{18: 0}\right)\end{array}$ & 1.99 & 2.18 & 2.01 & 2.03 & 2.46 \\
$\begin{array}{c}\text { Oleic acid } \\
\left(\mathrm{C}_{18: 1}\right)\end{array}$ & 15.55 & 14.57 & 14.22 & 14.12 & 14.96 \\
$\begin{array}{c}\text { Linoleic acid } \\
\left(\mathrm{C}_{18: 2}\right)\end{array}$ & 75.42 & 75.75 & 75.64 & 75.84 & 73.41 \\
$\begin{array}{c}\text { Others } \\
\text { Total saturated } \\
\text { fatty acids }\end{array}$ & 0.59 & 0.15 & 0.96 & 0.98 & 2.17 \\
$\begin{array}{c}\text { Total unsaturated } \\
\text { fatty acids }\end{array}$ & 90.97 & 9.53 & 9.18 & 9.06 & 9.5 \\
\hline \hline
\end{tabular}

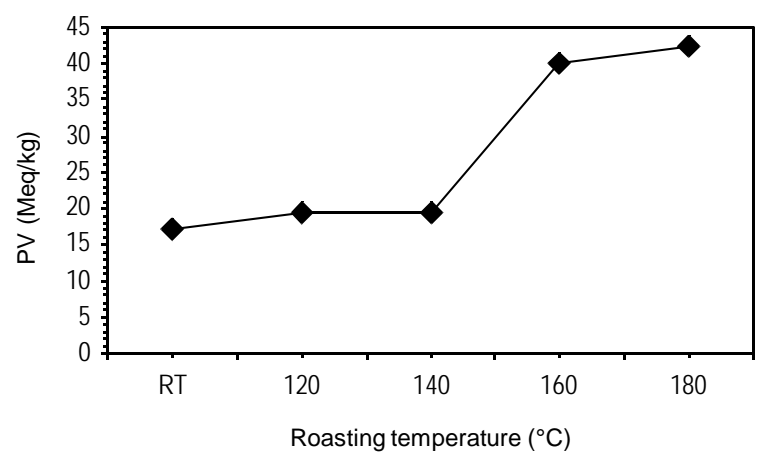

Fig. 2. PV values at different roasting temperatures $\left(\mathrm{RT}=35^{\circ} \mathrm{C}\right)$.

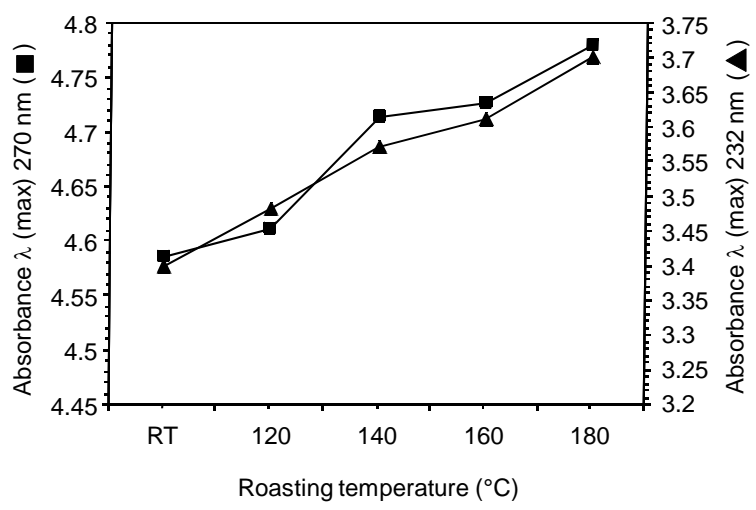

Fig. 3. Absorbance at 232 and $270 \mathrm{~nm}$ at different roasting temperatures $\left(\mathrm{RT}=35^{\circ} \mathrm{C}\right)$.

The colour formation during roasting of $C$. tinctorius Thori-78 seeds at 120, 140, 160 and $180{ }^{\circ} \mathrm{C}$ (Fig. 5) with the increase in temperature, resulted in significant

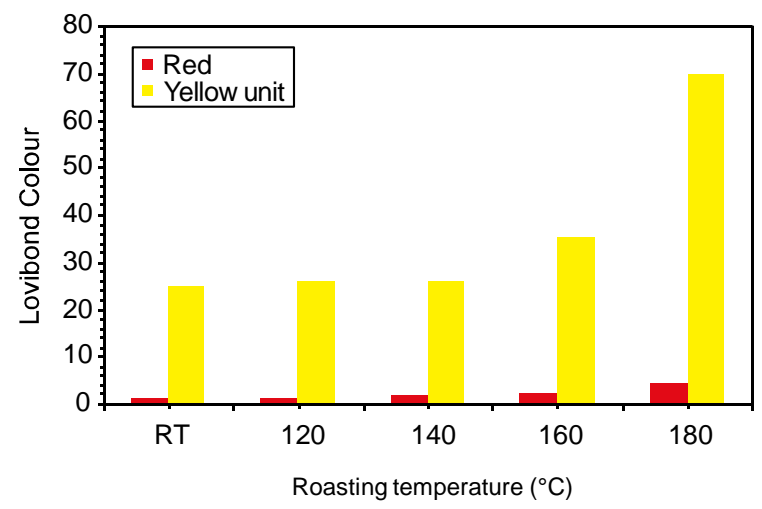

Fig. 4. Red and yellow units of unroasted and roasted seed oil samples $\left(\mathrm{RT}=35^{\circ} \mathrm{C}\right)$.

increase in the absorbance at $420 \mathrm{~nm}$ from 0.018 to 0.118 (light yellow to dark brown). As the temperature increased, the increase in colour of oils, seemed to be due to maillard type non-enzymatic reactions between sugars and free amino acids or amides in the seeds (Lee et al., 2004) resulting in brown colour substances in that seed samples. This result is in concordance with the earlier literature, reporting significant increase in colour of oils of rice germ, sesame seed and safflower (Lee et al., 2004, Kim et al., 2002a; Yoshida and Takagi, 1997; Yoshida, 1994; Yen, 1990).

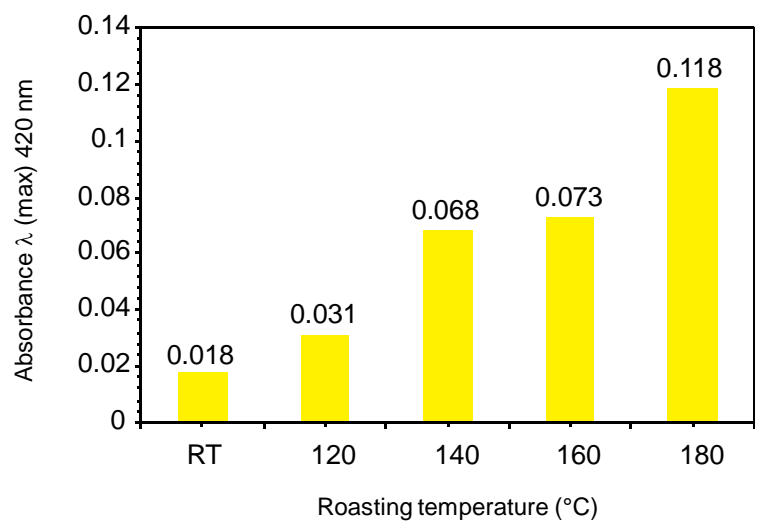

Fig. 5. Absorbance at $420 \mathrm{~nm}$ at different roasting temperatures $\left(\mathrm{RT}=35^{\circ} \mathrm{C}\right)$.

There was no observable significant variation in the refractive index determined at $40^{\circ} \mathrm{C}$; this showed that the high temperature did not affect the structure of oils of unroasted and roasted seeds. Thus the oils are fit for edible purposes. 
Densities of all samples were determined at 24 and $40^{\circ} \mathrm{C}$. There was no significant variation observed in density with rise in temperature as shown in Fig. 6; the values are in concordance with the reported values for vegetable oils (Rossell, 1991).

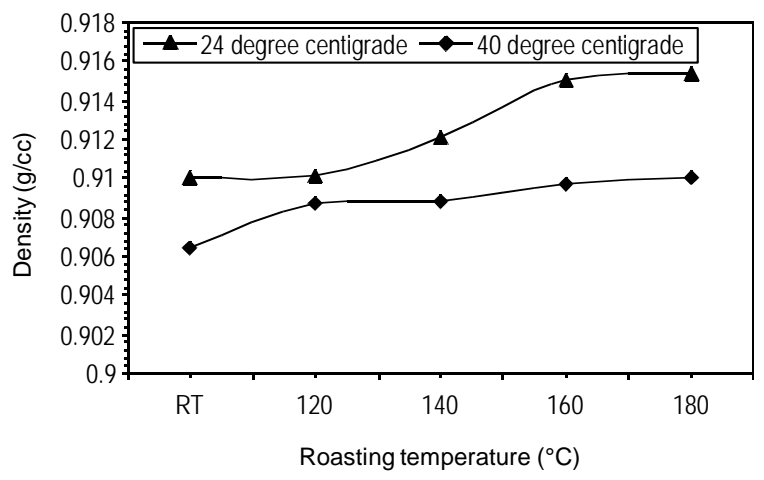

Fig. 6. Oil density at different roasting temperatures $\left(\mathrm{RT}=35^{\circ} \mathrm{C}\right)$.

With the increase in roasting temperature, unsaponifiable matter slightly increased (Table 1) but the values are concordant with the previous reports about unsaponfiable matter of vegetable oils (Rossell, 1991).

High iodine values of $C$. tinctorius is due to the presence of high content of unsaturated fatty acids and are comparable to the values obtained for poppy, soybean and sunflower oils (Rossell, 1991). High iodine values show that seed oil has good qualities of edible oil and drying oil (Eromosele et al., 1994); thus it can be put to different industrial uses. Iodine values of roasted and unroasted oil samples were more or less similar except the slight decrease at $180^{\circ} \mathrm{C}$. This is also confirmed by fatty acid composition of sample oil roasted at $180{ }^{\circ} \mathrm{C}$ (Table 2) with decrease in linoleic acid concentration from 75.42 to $73.41 \%$ and slight increase in stearic acid from 1.99 to $2.46 \%$. Similar observation was reported in the previous studies on roasted pumpkin seeds (Markovic et al., 2004). Fatty acid composition of all the extracted oil samples was determined using gas chromatography; one of the fatty acid profile of $C$. tinctorius is shown in Fig. 7 with the components depicted in Table 2. The principle fatty acid components in Thori-78 were palmitic $\left(\mathrm{C}_{16: 0}\right)$, stearic $\left(\mathrm{C}_{18: 0}\right)$, oleic $\left(\mathrm{C}_{18: 1}\right)$ and linoleic $\left(\mathrm{C}_{18: 2}\right)$ acids. Linoleic acid is predominantly present. The fatty acid composition was more or less similar to that of sunflower, soybean, corn and cotton seeds and C. tinctorius originating from different geographic regions (Cosgse et al., 2007, Rossell, 1991). C. tinctorius Thori-78 variety is high in linoleic acid content as compared to the other varieties, grown in Pakistan (Sultana et al., 2010).

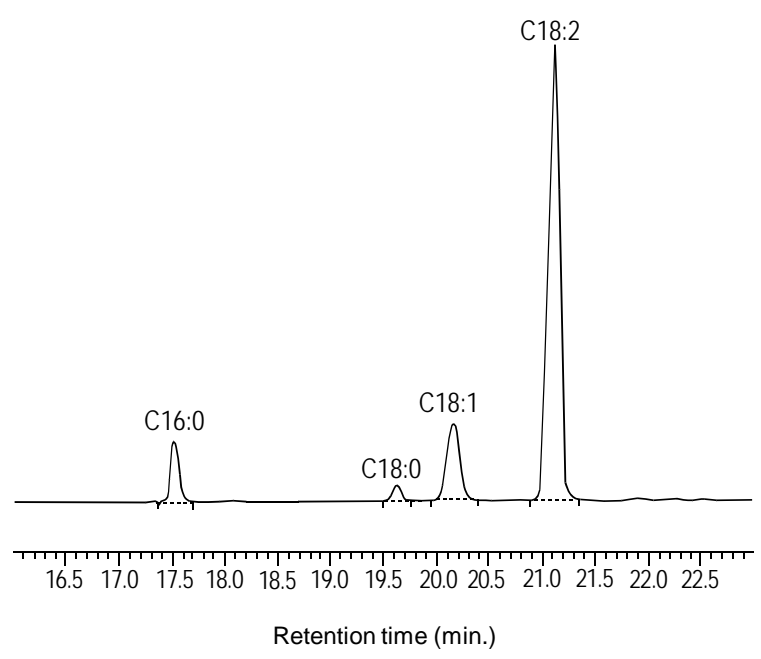

Fig. 7. Gas chromatogram of fatty acids of C. tinctorius (Thori-78) seed oil.

Characteristic parameters of roasted seed oil compared well with those of the oil samples of seeds roasted upto $160^{\circ} \mathrm{C}$, with no significant difference in the nutritional quality of oils. At the highest temperature $\left(180^{\circ} \mathrm{C}\right)$, however, maillard and non-enzymatic reaction occurred and the seeds were slightly burnt.

\section{Conclusion}

It is concluded that with the increase in roasting temperature the physicochemical characteristics of the roasted seed oil of $C$. tinctorius Thori-78 variety such as free fatty acid, acid value, rancidity, peroxide value and oxidative deterioration significantly increased while iodine value showed decreasing trend at $180^{\circ} \mathrm{C}$. This was also confirmed by fatty acid composition of sample oil roasted at $180{ }^{\circ} \mathrm{C}$ in which linoleic acid decreased and slight increase occurred in palmitic and stearic acids. Refractive index and densities of seed oil were relatively constant.

\section{References}

Albi, T., Lanzón, A., Gwinda, A., Pérezcamino, M.C., León, M. 1997. Microwave and conventional 
heating effects on some physical and chemical parameters of edible fats. Journal of Agricultural and Food Chemistry, 45: 3000-3003.

AOCS 2004. Official Methods and Recommended Practices of American Oil Chemists Society, $5^{\text {th }}$ edition, American Oil Chemist's Society, Champaign, Illinoise, USA.

Cosge, B., Gûrbûz, B., Kiralan, M. 2007. Oil content and fatty acid composition of some safflower (Carthamus tinctorius L.) varieties sown in spring and winter. International Journal of Natural and Engineering Science, 1: 11-15.

Duke, J.A. 1983. Hand Book of Energy Crops. [http:// www.hort.purdue.edu/newcrop/duke_energy/ Carthamus_tinctorius.html]

Eromosele, I.C., Eromosele, C.O., Akintoye, A.O., Komolafe, T.O. 1994. Characterization of oils and chemical analyses of the seeds of wild plants. Plant Foods for Human Nutrition, 46: 361-365.

Hamrouni, I., Touati, S., Dhifi, W., Chahed, T., Ayachi, S., Salah, H.B., Marzouk, B. 2004. Glycerolipid evolution during safflower seed formation and ripening. Journal of Food Lipids, 11: 297-311.

IUPAC 1987. Standard Methods for the Analysis of Oils, Fats and Derivatives, C. Paquot and A. Hautfenne (eds.), 96 pp., $7^{\text {th }}$ revised and enlarged edition, Blackwell Scientific Publications, London, UK.

Kaffka, S.R., Kearney, T.E., Knowles, P.D., Miller, M.D. 2000. Safflower production in California. [http://agric.uedavis. edu/agronomy/crops/oilseed/ safflower.html]

Khatoon, S., Krishna, A.G.G. 1998. Assessment of oxidation in heated safflower oil by physical, chemical and spectroscopic methods. Journal of Food Lipids, 5: 247-267.

Kim, I.H., Kim, C.J., You, J.M., Lee, K.W., Kim, C.T., Chung, S.H., Tae, B.S. 2002a. Effect of roasting temperature and time on the chemical composition of rice germ oil. Journal of American Oil Chemists Society, 79: 413-418.

Kim, H.J., Bae, Y.C., Park, R.W., Choi, S.W., Cho, S.H., Choi, Y.S., Lee, W.J. 2002b. Bone protecting effect of safflower seeds in ovariectomized rats. Calcified Tissue International, 71: 88-94.

Kim, I.H., Ki, M.H., Lee, Y.C. 1998. Oxidative stability and extraction of perilla seed oil with supercritical carbon dioxide. Food Science and Biotechnology, 7: 177-190.

Knights, S.E., Wachsman, N.G., Norton, R.M. 2001.
Safflower (Carthamus tinctorius L.) production and research in Southern Australia. In: Proceedings of the $5^{\text {th }}$ International Safflower Conference, pp. 213-217, North Dokota State University (Silliston), USA.

Lee, Y.C., Oh, S.W., Chang, J., Kim, I.W. 2004. Chemical composition and oxidative stability of safflower oil prepared from safflower seed roasted at different temperatures. Food Chemistry, 84: 1-6.

Mündel, H.H., Blackshaw, R.E., Byers, J.R., Huang, H.C., Johnson, D.L., Keon, R., Kubik, J., Mckenzie, R., Otto, B., Roth, B., Standford, K. 2004. Safflower production on the Canadian prairies: revisited in 2004. In: Agriculture and Agri-Food Canada, pp. 4-5, Graphcom Printers Ltd., Lethbridge, Alberta, Canada.

Murkovic, M., Piironen, V., Lampi, A.M., Kraushoffer, T., Sontag, G. 2004. Changes in chemical composition of pumpkin seeds during the roasting process for production of pumpkin seed oil. Part I: Non-volatile compounds. Food Chemistry, 84: 359-365.

Oelke, E.A., Oplinger, E.S., Teynor, T.M., Putnam, D.H., Doll, D.J., Kelling, K.A., Durgan, B.R., Noetzel, D.M. 1992. Safflower. In: Alternative Field Crops Manual, [http://www.hort.purdue. edu/newcrop/afcm/safflower.html]

Oyen, L.P.A., Umali, B.E. 2007. Carthamus tinctorius L., In: PROTA 14: Vegetable Oils/ Oléagineux, H.A.M. van der Vossen and G. S. Mkamilo (eds.), PROTA, Wageningen, Netherlands. [http://database. prota.org/PROTAhtml/Carthamus\%20 tinctorius_En.html]

Pritchard, J.L.R. 1991. Analysis and properties of Oilseeds. In: Analysis of Oilseeds, Fats and Fatty Foods, J. B. Rossell and J. L. R. Pritchard (eds.), 91 pp., Elsevier Applied Science, New York, USA.

Rossell, J.B. 1991. Vegetable oils and fats. In: Analysis of Oilseeds, Fats and Fatty Foods, J. B. Rossell and J. L. R. Pritchard (eds.), pp. 266-268, 290296, Elsevier Applied Science, New York, USA.

Sastri, B.N. 1950. The Wealth of India, A Dictionary of Indian Raw Materials and Industrial Products, vol. II, pp. 84-88.

Sultana, R., Saleem, R., Amrat. 2010. Physical and chemical evaluation of oils of two varieties of Carthamus tinctorius grown in Pakistan. Pakistan Journal of Sciencific and Industrial Research, 53: 14-19. 
Swern, D. 1964. Structure and composition of fats and oils. In: Bailey's Industrial Oil and Fat Products, D. Swern (ed.), pp. 211-212, John Wiley \& Sons, New York, USA.

Vieira, T.M.F.S., Regitano-D’Arce, M.A.B. 1998. Stability of oils heated by microwave: UV-spectrophotometric evaluation, Ciencia e Tecnologia de Alimentos, 18: 433-437.

Yen, G.C. 1990. Influence of seed roasting process on the changes in composition and quality of sesame (Sesame indicum) oil. Journal of Science of Food and Agriculture, 50: 563-570.
Yen, G.C., Shyn, S.L. 1989. Oxidative stability of sesame oil prepared from sesame seed with different roasting temperatures. Food Chemistry, 31: 215-224.

Yoshida, H., Takagi, S. 1997. Effects of seed roasting temperature and time on the quality characteristics of sesame (Sesamum indicum) oil. Journal of Science of Food and Agriculture, 75: 19-26.

Yoshida, H. 1994. Composition and quality characteristic of sesame seed (Sesame indicum) oil roasted at different temperature in an electric oven. Journal of Science of Food and Agriculture, 65: 331-336. 